\title{
Evaluation and Supervision System of College Students' English Listening Study Based on Data Analysis
}

\author{
Qu Meilin, Li Zeng, Tang Hui, Fei Jia \\ Beijing University of Posts and Telecommunications
}

\begin{abstract}
This study designed a college English listening evaluation and supervision system based on data analysis, in order to improve college students' English listening ability through this system. At the same time, 124 college students were randomly selected for a 4-month comparative experiment to test the effectiveness of using this system and team learning. The result of the data analysis shows that, this system can effectively improve students' English listening ability. If educators can analyze data appropriately and adjust the teaching plan, the quality of teaching can be improved.
\end{abstract}

Keywords-English listening; Data analysis; Information system; Education

\section{INTRODUCTION}

Studies have shown that people spend more than $42 \%$ of their time in listening when they use language to communicate [1]. Richards and other linguists believe that students' language skills will naturally improve after students' understanding skills are improved, and suggest listening training before speaking learning [2]. In general, language learning often needs a large amount of input, and listening, however, is one of the most important ways, which holds a balance of the whole language teaching. The best way to improve listening ability is to practice listening English materials and contact English as much as possible to enhance the sense of language [3]. The school's courses are limited, so it can't satisfy students' English learning needs. Therefore, students need listening practice outside class a lot. The development of independent learning ability helps students to improve their English proficiency.

On the other side, Bill Gates proposed at SXSW (South by Southwest Conference \& Festivals) that "The future of education is data". In the daily teaching activities, there will be a lot of data, which contains a lot of information. If we can effectively use the analysis, we can extract a lot of valuable information from it. Liang Wenxin believes that data analysis will help educators solve many education problems, transforming from reliance on limited educational experience to scientific data cases analysis, which will effectively improve students' learning quality.[4] Li Yihua believes that educators should master the technology of data processing and analysis, and mine the value contained in the data, so as to so as to improve the level of teaching.[5] From a macro perspective, Chen Shuangye and others put forward "evidence-based" education reform concept: In the information age, data analysis should be used to guide educational reform.[6] At present, there exists large promotion space in English learning and selflearning ability for Chinese college students, and the students self-learning mode based on data analysis will also have a long way to go [7].

In addition, this study designed a questionnaire with a sample size of 300 for the students of the International College of Beijing University of Posts and Telecommunications, with the aim to explore contemporary college students' problems in autonomous learning of English listening. The results showed that, $41.94 \%$ of the students showed that among the four skills in English "listening, speaking, reading and writing", the most urgent part needs to be improved is listening, and $48.39 \%$ of the students believe that the biggest obstacle in the current process of English autonomous learning is inertia; and over $70 \%$ of the students demonstrates that they have not ever developed English learning plans or formulated plans but performed poorly. This result shows that the college students have high enthusiasm for listening study, but the performance force is poor when it comes to action. Therefore, learning evaluation and corresponding supervision are essential in the autonomous learning of English listening.

At present, there are some software or online forums related to English listening at home and abroad, but the forms are mostly resource sharing, that is, providing daily materials for everyone to learn, and can not play the role of evaluation and supervision. Therefore, this study designed a college students' evaluation and supervision system of English listening learning based on data analysis, aiming to improve students' English listening ability and test the effects of their self-learning of English listening through the data analysis.

\section{SYSTEM SYNOPSIS}

\section{A. Basic contents}

The main content of this project is to design a system to supervise students to finish the extracurricular English listening plans independently, to evaluate and encourage students, and to publish some materials related to English listening learning for users' reference. Nowadays, college students have not enough classroom listening time, thereby, to make English a tool of communication, it is very necessary to have enough listening practice, so we want to provide college students with a 
platform to help and urge them to finish their extracurricular listening plans.

Therefore, we designed a real-name registration system. Firstly, students themselves formulate weekly listening plans and then seek books or webs to finish their plans. Secondly, they submit credentials on the system, including name, class, student number, and listening material. System makes an evaluation according to students' learning feedback automatically every week, and give some advice for their listening plans. Project team members will also conduct a more holistic and detailed assessment for students' listening contents Not only that, the system will also provide feedback on the evaluation of students' listening plans. The specific operations is: After the user submits the weekly listening plan, the platform will automatically analyze its plan and evaluate whether the hearing time distribution is reasonable, and compares the plan with the previous weeks plan, and whether the evaluation materials are reasonable, and then It generates feedback and evaluates the user's plan. We hope through this system, college students can develop a good habit of practice English listening every day, so as to improve their English ability. Able to understand everyday English conversations and notifications; to be able to understand the central ideas of $\mathrm{BBC}$ radio, television programs, or other English listening materials, which are long and moderate in everyday topics

In addition, we designed a "listening partner" team learning part, that is, each student participating in this session will be assigned a corresponding listening partner. The two students can exchange and share learning experiences and skills, enhance their autonomy and enthusiasm, and the interest of English listening. Listening partners can supervise and remind each other to perform listening training, improve their English listening abilities, and make progress together.

\section{B. System characteristics}

To improve listening ability is not a day's work. It requires students to develop good habits, spend a fixed period of time every day to do extensive listening (understand the general content of the materials) or intensive listening (accurate listening training, capture every word and phrase in the listening material) practice, review and consolidate the words accumulated in intensive listening. Make detailed plans, select appropriate materials and persevere for a period of time, then students' listening ability can be greatly improved. Through the supervision and evaluation of students' listening plans, the system can urge students to finish the listening plans, avoid students from developing listening plans that are not implemented afterwards, and thus improve their English ability. Especially for students with less consciousness, the effects are particularly obvious.

\section{EXPERIMENT DESIGN AND PROCESS}

This study took 124 students from four classes of grade 2017, International College of Beijing University of Posts and Telecommunications as the experimental subjects. The four classes have the same English courses and teachers. Randomly selected two classes, a total of 64 people as an experimental group using the English listening learning evaluation and supervision system of college students based on data analysis, namely the autonomous learning group. The other classes students, a total of 60 students, were taken as the control group. From September 2017 to January 2018, the experimental group used the listening system to conduct listening training after class. The students' self-made learning plans and performance can be checked through the system, the control group performed listening exercises by the traditional method, and among the autonomous learning group, 32 people were selected for the "listening partner" team as an experimental group (team group), and the remaining students as a control group. Taking the listening scores of 2017 International College English Proficiency Test as the pretest data, and after a semester's study, selected the listening scores of these four classes students in the final exam in January 2018 as post-test data to measure their listening levels at the end of the experiment.

\section{DATA ANALYSIS AND DISCUSSION}

This study used Microsoft EXCEL and SPSS software to process and analyze data, and independent sample t test was used to measure whether there was an obvious difference in English listening ability between the two groups students using and not using the systems before the experiment. The independent sample $t$ test was used to determine whether there was a significant difference in the English listening level between the experimental group and the control group; the paired sample t test was used to judge whether the students' listening level was improved after the use of the system and the team learning.

TABLE I ENGLISH LISTENING PERFORMANCE

\begin{tabular}{|c|c|c|c|c|}
\hline & & Sample size & Average scores & Variance \\
\hline \multirow{2}{*}{ System pretest results } & Experimental group & 64 & 70.67 & 71.40 \\
\hline & Control group & 60 & 69.88 & 57.45 \\
\hline \multirow{2}{*}{ System post test results } & Experimental group & 64 & 74.88 & 72.32 \\
\hline & Control group & 60 & 70.56 & 93.51 \\
\hline \multirow{2}{*}{ Team pretest results } & Experimental group & 32 & 68.14 & 79.92 \\
\hline & Control group & 32 & 69.41 & 95.84 \\
\hline \multirow{2}{*}{ Team post test results } & Experimental group & 32 & 72.13 & 151.3 \\
\hline & Control group & 32 & 70.11 & 139.2 \\
\hline
\end{tabular}


TABLE II PRETEST RESULTS INDEPENDENT SAMPLE T TEST

\begin{tabular}{|c|c|c|c|c|c|c|}
\hline & & \multicolumn{2}{|c|}{ Levene test with equal variance } & & \multicolumn{2}{|c|}{ Test with equal average scores } \\
\hline & & $\begin{array}{c}F \\
\text { Variance }\end{array}$ & $\begin{array}{c}\text { Sig } \\
\begin{array}{c}\text { Variance equal } \\
\text { probability }\end{array}\end{array}$ & $t$ & $\begin{array}{c}\text { Df } \\
\text { Degree of } \\
\text { freedom }\end{array}$ & $\begin{array}{c}\text { Sig } \\
\text { Two-tailed test } \\
\text { probability }\end{array}$ \\
\hline \multirow{2}{*}{$\begin{array}{c}\text { System } \\
\text { pretest } \\
\text { scores }\end{array}$} & $\begin{array}{c}\text { Assuming equal } \\
\text { variance }\end{array}$ & 2.671 & 0.114 & 0.038 & 183 & 0.912 \\
\hline & $\begin{array}{c}\text { Assuming unequal } \\
\text { variances }\end{array}$ & & & 0.04 & 179.28 & 0.958 \\
\hline \multirow{2}{*}{$\begin{array}{c}\text { Team } \\
\text { pretest } \\
\text { scores }\end{array}$} & $\begin{array}{c}\text { Assuming equal } \\
\text { variance }\end{array}$ & 0.631 & 0.42 & 0.978 & 183.39 & 0.451 \\
\hline & $\begin{array}{c}\text { Assuming unequal } \\
\text { variances }\end{array}$ & & & 0.964 & 184.54 & 0.329 \\
\hline
\end{tabular}

The test results of homogeneous variance before using the system were $\mathrm{F}=2.671, \mathrm{P}=0.113>0.0$ and $\mathrm{T}=0.038$, as well as the results of the test in Table $2, \mathrm{P}=0.912>0.05$ indicate that the system learning experiment group and the control group students' initial listening ability were basically

On the other side, the test results of the homogeneous variance for team learning pretest scores in Table II were $\mathrm{F}=$ $0.631, \mathrm{P}=0.42>0.05$, which means that the variances of the two groups are equal; Table I shows that the scores of the experimental group are lower than the control group by same. After the test group used a one-semester listening monitoring system, a paired sample t-test was performed on the scores of the two groups to judge whether the listening level of the two groups was improved.

$69.2947>67.9451$, but the results of the $t$ test (Table 2) $t=$ $0.978, \mathrm{P}=0.451>0.05$, indicate that there was no significant difference in the initial listening level learning between the team and non-team learning students .

TABLE III T TEST CORRELATION COEFFICIENT

\begin{tabular}{|c|c|c|c|}
\hline & N(Sample size) & $\begin{array}{c}\text { Correlation } \\
\text { (correlation coefficient) }\end{array}$ & 0.257 \\
\hline $\begin{array}{c}\text { Pretest and post- test scores of system experimental } \\
\text { group }\end{array}$ & 64 & 0.413 & $\mathrm{P}_{2}=0.016$ \\
\hline Pretest and post- test scores of system control group & 60 & 0.586 & $\mathrm{P}_{1}=0.000$ \\
\hline $\begin{array}{c}\text { Pretest and post- test scores of team experimental } \\
\text { group }\end{array}$ & 32 & 0.709 & $\mathrm{P}_{4}=0.006$ \\
\hline Pretest and post- test scores of team control group & 32 & $\mathrm{P}_{3}=0.002$ \\
\hline
\end{tabular}

P1, P2, P3, P4 <0.05 indicated that the scores before and after the experiment in all groups were significantly correlated.

TABLE IV T TEST FOR TWO GROUPS OF POST- TEST SCORES INDEPENDENT SAMPLES

\begin{tabular}{|c|c|c|c|c|c|c|}
\hline & & \multicolumn{2}{|c|}{ Levene test with equal variance } & \multirow[b]{2}{*}{$t$} & \multicolumn{2}{|c|}{ Test with equal average scores } \\
\hline & & $\begin{array}{c}F \\
\text { Variance }\end{array}$ & $\begin{array}{c}\text { Sig } \\
\text { Variance equal } \\
\text { probability }\end{array}$ & & $\begin{array}{c}\text { Df } \\
\text { Degree of } \\
\text { freedom }\end{array}$ & $\begin{array}{c}\text { Sig } \\
\text { Variance equal } \\
\text { probability }\end{array}$ \\
\hline \multirow{2}{*}{$\begin{array}{l}\text { System } \\
\text { pretest } \\
\text { scores }\end{array}$} & $\begin{array}{c}\text { Assuming equal } \\
\text { variance }\end{array}$ & 1.948 & 0.172 & -1.783 & 183 & 0.082 \\
\hline & $\begin{array}{c}\text { Assuming unequal } \\
\text { variance }\end{array}$ & & & -1.764 & 182.863 & 0.079 \\
\hline \multirow{2}{*}{$\begin{array}{c}\text { Team } \\
\text { pretest } \\
\text { scores }\end{array}$} & $\begin{array}{c}\text { Assuming equal } \\
\text { variance }\end{array}$ & 0.139 & 0.756 & 1.562 & 183 & 0.148 \\
\hline & $\begin{array}{c}\text { Assuming unequal } \\
\text { variance }\end{array}$ & & & 1.577 & 183.781 & 0.148 \\
\hline
\end{tabular}

In Table VI, the test of homogeneity of the post-test results of the experimental group and the control group of the team studied was $\mathrm{F}=0.139, \mathrm{P}=0.756>0.05$, indicating that the test scores of the two teams were equal after learning, and then we performed the $\mathrm{t}$-test. As $\mathrm{t}=1.562, \mathrm{P}=1.577 \mathrm{>}$ 0.05 , indicating that there is no significant difference in the scores of the two groups after learning with team, it can not explain that the listening level of the team learning group is higher than the non-team group. Therefore, it could not be explained that the listening level of the team learning group was higher than that of the non-team group.
The test results of the homogeneous variance of the two groups (team learning experimental group and control group) after using the system were $\mathrm{F}=1.948, \mathrm{P}=0.172>0.05$, indicating that the variance of the two groups scores was equal after the use of the system. In this condition, the t test results were $\mathrm{t}=1.783,0.09>\mathrm{P}=0.082>0.05$, showing that there was a significant difference in the probability of $91 \%$ of the scores in these two groups after using the system, which means that this system is able to help improve students' listening ability. 


\section{CONCLUSIONS}

The test results showed that: 1.The audiometric scores of the experimental group and the control group are both significantly improved; 2 . The listening scores of the experimental group using the listening system were quite higher than that of the control group without using the system, it is clear that using this college student's English listening study evaluation and supervision system based on data analysis is able to improve college students' English listening ability; 3 . There was no significant improvement in team-learning students' listening scores, which shows that team learning has less helpful effect on improving students' listening level.

In this study, the English listening study evaluation and supervision system based on data analysis can obviously improve learners' listening ability, and can supervise and guide students' listening training on their spare time, and cultivate students' interest in English listening learning and self-learning ability so as to improve their English listening ability. Hence, it is evident that data analysis plays an important role in English listening teaching, even in English teaching. Data analysis has broken the stereotype of traditional teaching, enabling educators to find out the problems in teaching and the needs of students, improving their teaching plans, and students could receive more efficient and comprehensive education. Now we are in the information era of "using data to promote education", educators should make good use of modern information technology to promote profound changes in teaching models and learning methods, and promote the development of educational modernization in return. (Guide teacher: Chen Jing, Beijing University of Posts and Telecommunications)

\section{REFERENCES}

[1] P Cooper, Communication for the Classroom Teacher, G. Scarisbrick, 1988

[2] JC Richards, J Platt, H Platt, Longman dictionary of language teaching and applied linguistics,

[3] Cheng Jingyan, Current situation and development trend in English listening teaching, "foreign language community", 2009 (1) :51-56 (In Chinese)

[4] Liang Wenxin, Era of big data - classroom teaching will usher in a real change, "Journal of Beijing Institute of Education (Natural Science Edition)", 2013 , 8 (1) :14-16(In Chinese)

[5] Li Yihua, Yang Xiaohua, School Management Reform in the Era of big data, "Teaching and Management", 2014 (18):47-49. (In Chinese)

[6] Chen Shuangye, Meng Liujin, Zhang Haiyan, Educational Policy Evidence in the Era of Big Data: the Enlightenment of evidencebased idea on the Modernization of Education Governance and Scientific Decision-making in China, "Global education outlook", 2014, 43 (2) :121-128. (In Chinese)

[7] Zhang Lingli, Study on network autonomous learning mode of English Listening based on goals orientation. "Foreign language audio-visual education", 2009 (5): 46-50. (In Chinese) 